\title{
INFLUENCE OF THE DIALYSIS MEMBRANE TYPE ON QUALITY OF LIFE, CLINICAL OUTCOMES AND LABORATORY PARAMETERS IN PATIENTS UNDERGOING HAEMODIALYSIS
}

Jelena Soldatovic ${ }^{1}$

${ }^{1}$ The haemodialysis centre in the Studenica Regional Health Centre, Kraljevo

\author{
UTICAJ VRSTE DIJALIZNE MEMBRANE NA IVALITET ŽIVOTA, \\ KLINIČKE ISHODE I LABORATORIJSKE PARAMETRE PACIJENATA \\ NA HEMODIJALIZI
}

\author{
Jelena Soldatovic \\ ${ }^{1}$ Hemodijalizni centar regionalnog Zdravstvenog centra „Studenica “ u Kraljevu
}

Received / Primljen: 13. 03. 2012.

Accepted / Prihvaćen: 26. 03. 2012.

\begin{abstract}
Background: High-flux haemodialysis uses dialysis membranes of significant porosity to permit the passage of larger molecules ( $\beta 2-$ microglobulin clirens $>20 \mathrm{ml} / \mathrm{min}$ ) and allows a higher coefficient of ultrafiltration (CUF $>15 \mathrm{ml} / \mathrm{mmHg}$ per hour). Preliminary results found that anaemia was more easily corrected among patients treated with high-flux membranes, while randomised trials failed to prove a significant effect. Total blood triglycerides, VLDL triglycerides and VLDL cholesterol decreased, and HDL cholesterol increased in the polysulphone high-flux group, while these variables remained unchanged in a group of patients treated with standard dialysers.
\end{abstract}

Objective: Comparisons were made between patients treated with high-flux membrane dialysers and patients treated with low-flux membrane dialysers with regard to quality of life, clinical outcomes and laboratory results.

Methods: The study was investigator-driven, crosssectional and based on the intention-to-treat principle. The study population was composed of patients undergoing dialysis treatment (18 to 70 years of age) in the Studenica regional health centre in Kraljevo.

The patients belonged to the low-flux haemodialysis group $(n=33)$ or the high-flux haemodialysis $(n=39)$ group. The patients were interviewed between December 2009 and January 2010. The results of laboratory tests and data on comorbidities were obtained from medical records. Information regarding quality of life and habits were obtained using the Comprehensive Quality of Life Scale - Adult.

Results: Serum levels of urea were significantly different between patients who were treated with high-flux membrane dialysers and those who were treated with low-flux membrane dialysers ( $t=2,094, p=0.040)$. No significant differences were found regarding other laboratory parameters, clinical symptoms, comorbidities, habits, or patients' quality of life.

Conclusion: Although high-porosity high-flux haemodialysis membranes remove waste solutes more efficiently than low-flux membranes with smaller pores, this fact did not translate into significant differences in patients' quality of life.

Keywords: Dialysers, quality of life, laboratory analysis

\section{SAŽETAK}

Uvod : U hemodijalizi visokog fluksa koriste se dijalizne membrane značajne poroznosti za veće molekule (klirens ß2- mikroglobulina $>20 \mathrm{ml} / \mathrm{min}$ ) $i$ omogućen je koeficijent ultrafiltracije veći od $15 \mathrm{ml} / \mathrm{mmHg}$ po satu. Preliminarni rezultati su ukazivali da se anemija lakše koriguje u pacijenata koji su na membranama visokog fluksa,dok randomizirane studije nisu uspele da dokažu značajan efekat. Ukupni krvni trigliceridi, trigliceridi i holesterol veoma male gustine ( VLDL) su opali, a holesterol visoke gustine (HDL) je porastao u polisulfonskoj grupi visokogfluksa, dok su navedene varijable ostale neizmenjene u grupi pacijenata na standardnim dijalizatorima.

Cilj: Napravljeno je poređenje izmedu pacijenata na hemodijalizi visokog $i$ hemodijalizi niskog fluksa u pogledu kvaliteta života, kliničkog ishoda i laboratorijskih rezultata.

Metod: Studija je sprovedena kao studija preseka. Studijsku populaciju su sačinjavali pacijenti na dijaliznom tretmanu (u rasponu od 18 do 70 godina starosti) u regionalnom zdravstvenom centru, Studenica " u Kraljevu.

Pacijenti su bili ili na hemodijalizi niskog fluksa (njih 33) ili hemodijalizi visokog fluksa (njih 39). Pacijenti su intervjuisani u periodu od decembra 2009. do januara 2010. Rezultati laboratorijskih testova $i$ podaci o komorbiditetu su dobijeni iz zdravstvenih kartona. Informacije o kvalitetu života $i$ navikama su dobijeni iz Comprehensive Quality of Life Scale-Adult".

Rezultati: Serumski nivoi uree su bili značajno različiti između pacijenata na dijalizatorima visokog fluksa $i$ onih na dijalizatorima niskog fluksa ( $t=2.094, p=0.040)$. Za druge laboratorijske parametre, kliničke simptome, navike i kvalitet života-značajne razlike nisu nađene.

Zaključak: Mada visoka poroznost hemodijaliznih membrana omogućava uklanjanje raspadnih produkata efikasnije nego kod membrana niskog fluksa koje imaju manje pore, ta činjenica nije dovela do značajnih razlika u kvalitetu života pacijenata.

Ključne reči: Dijalizatori, kvalitet života, laboratorijske analize 


\section{INTRODUCTION}

In patients with terminal renal insufficiency, toxins accumulate in the blood because the kidneys lose their ability to properly eliminate these substances. High-flux haemodialysis uses dialysis membranes of significant porosity to allow the passage of larger molecules, which allows a high coefficient of ultrafiltration (CUF $>15 \mathrm{ml} / \mathrm{mmHg}$ per hour).

Although the use of new haemodialysis modalities has grown, the clinical risks and benefits of these high-performance therapies are not well defined. In the literature published in the past ten years, definitions of high-efficiency and high-flux dialysis are confusing. At the moment, the quantity of dialysis treatment is defined not only by time, but also by dialysator characteristics, velocity of blood and dialysate circulation. In the past, when the efficiency of dialysis and the circulation had a tendency to be low, the quantity of dialysis treatment was well defined by time. Today, duration of dialysis treatment is not a useful expression of treatment quantity because the efficiency is highly variable.

Preliminary results found that there was an actual benefit in the correction of anaemia in patients treated with high-flux membranes, while randomised trials failed to prove a significant effect. Total blood triglycerides, VLDL triglycerides and VLDL cholesterol decreased, and HDL cholesterol increased in the polysulphone high-flux group, while these variables remained unchanged in group of patients treated with standard dialysers. (1)

A controlled prospective study investigated the change in lipid parameters from dialysis with cellulose membranes (which are low-flux membranes) to polysulphone membranes (which are high-flux membranes). Total serum triglycerides and VLDL cholesterol decreased, and the proportion of HDL cholesterol increased in the polysulphone high-flux group, while these variables remained unchanged in the control group. The LDL and total cholesterol, parathyroid hormone, albumin, and body weight remained unchanged. (2)

The HEMO study did not show a statistically significant effect of higher dialysis dose and high-flux membranes on survival and morbidity $(3,4)$, but it noted that chronic kidney insufficiency is a major reason for hospitalisation from cardiac diseases. The use of high- or low-flux membranes exhibited no difference in laboratory values in a study that investigated the effect of different synthetic membranes on laboratory parameters and survival in chronic haemodialysis patients. (4)

Though high-flux haemodialysis did not decrease mortality from all causes among those with cardiac diseases, it has been shown to improve other outcomes among patients with cardiac diseases. (5) Patients with diabetes have also shown a significant survival benefit when treated with high-flux haemodialysis. (6)

Due to their high porosity, high-flux membranes are able to remove waste solutes of higher molecular weight compared to low-flux membranes (7), which have smaller pores. However, it is not clear whether this amplified elimination of waste solutes confers a long-term benefit of long-term survival among patients treated with high-flux membranes.

The aim of our study was to investigate the influence of dialysator type on quality of life, clinical status and values of laboratory analyses among patients undergoing haemodialysis.

\section{MATERIALS AND METHODS}

\section{Study type}

This study was observational and cross-sectional and aimed to investigate the influence of dialysator type on quality of life, clinical status and laboratory analyses of patients undergoing haemodialysis.

\section{The study population}

This study was conducted in the Haemodialysis department of the Studenica Health Centre in Kraljevo, Serbia, from December 2009 to February 2010. The study population included all patients undergoing haemodialysis encountered during that period who agreed to participate in the study and who underwent haemodialysis for at least one year. The following patients were excluded from the study: those under age eighteen or over age seventy, patients with malignancy, patients undergoing chemotherapy, pregnant women, patients with portal hypertension and those who declined participation in the study.

\section{The study groups}

Patients were separated into two groups based on their exposure to high-efficacy haemodialysis during the year 2009. The patients belonged either to the low-flux haemodialysis $(n=33)$ group or the high-flux haemodialysis $(n=39)$ group. The patients were interviewed between December 2009 and January 2010. The results of laboratory tests and data on comorbidities were obtained from medical records. Information regarding quality of life and habits was obtained from the Comprehensive Quality of Life Scale - Adult. $(8,9,10)$ All information was anonymous, patient consent was obtained, and the study was approved by the Ethical Committee of the Studenica Health Centre in Kraljevo.

\section{The study variables}

The following categorical variables were taken into account: symptoms of patients undergoing haemodialysis (headache, respiratory discomforts, and urinary discomforts), diagnosis of cardiac insufficiency, use of erythropoietin (more than six months), parenteral iron preparations (more than six months), presence of GIT bleeding, data about habits (cigarette smoking and alcohol), co-morbidities and the results of the life quality questionnaire. The following continuous variables were taken into account: serum values of urea, creatinine, sodium, potassium, calcium, phosphorus, proteins, cholesterol, alkaline phosphatase, iron, haematocrit, eryth- 
rocytes, haemoglobin, leukocytes, thrombocytes, MCV (mean corpuscular volume), and body mass index.

\section{Statistics}

The prevalence of each characteristic during the study period was determined for both groups. Differences in the observed characteristics were assessed between patients who were treated with high-flux membrane dialysers and patients who were treated with low-flux membrane dialysers using an independent T-test for continuous variables and a Chi-squared test for frequencies. The differences were considered significant if the probability of the null hypothesis was less than 0.05 . The statistical calculations were made using the SPSS statistical package (version 18).

\section{RESULTS}

Serum levels of urea were significantly different between patients who were treated with high-flux membrane dialysers and those who were treated with low-flux membrane dialysers $(t=2,094, p=0.040)$ No significant differences were found in other laboratory parameters, clinical symptoms, co-morbidities, habits, or quality of life (Table 1).

\section{DISCUSSION}

The different permeabilities of dialysis membranes lead to different removal capacities, particularly for uremic toxins of middle and large molecular weight. High-flux dialysers have been evaluated in clinical and epidemiological studies for their effects on mortality, morbidity, dialysisrelated data and the preservation of residual renal function. However, many of these studies lack a prospective design and randomised treatment allocation, or they have too few patients and too short a period of follow-up. In this study, there was a significant difference in the serum urea levels among patients who were treated with different flux membranes, and it is believed that highly permeable dialysis membranes with a large pore size are more efficient than membranes with a small pore size for the removal of middle-sized molecules of uremic toxins.

Haemodialysis with high-flux membrane dialysers and haemodiafiltration were both connected to reductions of the pretreatment beta 2 microglobulin level, but the reduction was much greater in haemodiafiltration. Haemodialysis with high-flux membrane dialysers and haemodiafiltration of renal replacement therapy modes led to better nutritional status and to a better response to $\mathrm{rHu}$ EPO in patients with anaemia. Regarding sodium and energy balance, haemodiafiltration resulted in a much lower number of hypotensive episodes and an improvement in the quality of life (11).

Removal of small solutes (urea and creatinine) and larger solutes, such as b2-microglobulin and complement factor $D$, is much better with haemodiafiltration than with haemodialysis with high-flux membranes. Concentrations of pretreatment plasma complement factor D decreased more greatly with time among patients undergoing haemodiafiltration than among patients undergoing haemodialysis with high-flux membrane dialysers.(12)

During the beginning of dialysis treatment, serum potassium concentrations tend to decrease rapidly in the dialysate and to cause lower systolic and mean blood pressure by altering peripheral resistance. It has been concluded that the risk for developing intra-dialysis hypotension is strongly correlated with the dialysate potassium concentration.(13)

High-flux membranes showed a benefit in the lowering of plasma triglyceride, which has been confirmed elsewhere. (14)

Previous studies have reported controversial information. However, a study that investigated the effect of different synthetic membranes on laboratory parameters and survival among patients with ESRD (end-stage renal disease) found no differences in laboratory parameters between patients treated with high- or low-flux membranes.

A secondary study, the HEMO Study, aimed to examine the changes in health-related quality of life. It offered the specific hypotheses that study interventions would have a large impact on physical functioning, vitality, Short Form-36 Health Survey (SF-36) scores of physical and mental component summaries, kidney disease symptoms and problems and sleep quality. In that trial, among patients undergoing haemodialysis three times a week, the SF-36 physical component summary score and pain scale showed a benefit in the clinical status with higher dialysis dose, especially among patients who underwent dialysis treatment three times per week. Dose or flux interventions showed no benefit that was clinically meaningful, especially regarding other indices of health-related quality of life.( 5)

A study that examined middle-sized molecules, highflux membranes, and optimal dialysis (15), and a randomised trial of high-flux vs. low-flux haemodialysis on the effects on homocysteine and lipids (16), showed that highly permeable dialysis membranes with a large pore size are more efficient in the removal of middle-sized molecules such as homocysteine and lipids. Regarding the removal of urea $(\mathrm{Kt} / \mathrm{V})$ and phosphate, greater removal was observed with online haemodiafiltration than in haemodialysis. In a study that investigated dialysis dose and membrane flux impact on parameters of nutrition, neither mean serum albumin levels nor mean post-dialysis weight were significantly affected (17). The mean erythrocyte sedimentation rate declined more significantly in patients treated with high-flux membrane dialysers compared to patients treated with low-flux membrane dialysers.

Nutritional parameters can be altered subtly by interventions targeting the dose and flux, but nothing has been shown to prevent deterioration in nutritional status over time. (2)

Higher dialysis dose or high-flux membrane dialysers have not been shown to improve survival or reduce morbidity among patients undergoing maintenance haemodialysis, which is in contrast to the results of observational 
Table 1. Values of measured variables in the study groups.

\begin{tabular}{|c|c|c|c|c|c|}
\hline & $\begin{array}{l}\mathrm{HDF} \\
(\operatorname{mean} \pm \mathrm{SD}) \% \mathrm{n}(\%)^{+}\end{array}$ & $\begin{array}{l}\text { Non-HDF } \\
(\text { mean } \pm \text { SD }) \% n(\%)^{+}\end{array}$ & $\begin{array}{l}\text { Values of } \\
\text { independent } \\
\text { samples T-test }\end{array}$ & $\begin{array}{l}\text { Values of } \\
\text { Chisquared } \\
\text { test }\end{array}$ & $\mathrm{p}$ Value \\
\hline Urea & $17,761 \pm 3,469$ & $20,309 \pm 6,604$ & 2,094 & & 0,04 \\
\hline Creatinine & $640,161 \pm 118,521$ & $591,705 \pm 159,29$ & $-1,478$ & & 0,144 \\
\hline Sodium & $136,518 \pm 1,987$ & $136,161 \pm 1,951$ & 0,767 & & 0,446 \\
\hline Potassium & $4,466 \pm 0,432$ & $4,315 \pm 0,727$ & 1,045 & & 0,3 \\
\hline Calcium & $2,403 \pm 0,155$ & $2,382 \pm 0,191$ & $-0,506$ & & 0,615 \\
\hline Phosphorus & $1,628 \pm 0,325$ & $1,694 \pm 0,369$ & 0,807 & & 0,422 \\
\hline Proteins & $67,713 \pm 4,635$ & $67,365 \pm 5,61$ & 0,286 & & 0,776 \\
\hline Cholesterol & $4,419 \pm 0,938$ & $4,712 \pm 0,871$ & $-1,355$ & & 0,18 \\
\hline $\begin{array}{l}\text { Alkaline } \\
\text { phosphatase }\end{array}$ & $92,441 \pm 46,749$ & $82,720 \pm 32,298$ & $-0,997$ & & 0,322 \\
\hline Iron & $12,994 \pm 5,978$ & $11,497 \pm 3,613$ & 1,256 & & 0,213 \\
\hline Haematocrit & $288,634 \pm 50,923$ & $281,280 \pm 38,486$ & $-0,681$ & & 0,498 \\
\hline Haemoglobin & $97,456 \pm 9,928$ & $93,132 \pm 12,304$ & $-1,650$ & & 0,103 \\
\hline Erythrocytes & $3,075 \pm 0,379$ & $2,965 \pm 0,459$ & $-1,108$ & & 0,272 \\
\hline Leukocytes & $6,333 \pm 1,740$ & $7,010 \pm 1,888$ & 1,582 & & 0,118 \\
\hline Thrombocytes & $199,346 \pm 73,119$ & $218,303 \pm 62,108$ & $-1,173$ & & 0,245 \\
\hline $\mathrm{MCV}$ & $95,779 \pm 5,297$ & $94,465 \pm 3,685$ & $-1,200$ & & 0,234 \\
\hline BMI & $24,019 \pm 4,407$ & $24,184 \pm 4,317$ & $-0,152$ & & 0,88 \\
\hline Headache & $23(58,974 \%)$ & $23(69,697 \%)$ & & 0,345 & 0,461 \\
\hline $\begin{array}{l}\text { Respiratory } \\
\text { discomfort }\end{array}$ & $25(64,103 \%)$ & $17(51,515 \%)$ & & 0,28 & 0,341 \\
\hline Urea & $17,761 \pm 3,469$ & $20,309 \pm 6,604$ & 2,094 & & 0,04 \\
\hline $\begin{array}{l}\text { Urinary } \\
\text { discomfort }\end{array}$ & $3(7,692 \%)$ & $6(18,182)$ & & 0,194 & 0,287 \\
\hline $\begin{array}{l}\text { Cardiac } \\
\text { insufficiency }\end{array}$ & $6(15,385 \%)$ & $7(21,212 \%)$ & & 0,522 & 0,554 \\
\hline GIT bleeding & & & & 0,992 & 1 \\
\hline Alcohol & $3(7,692)$ & $4(12,121)$ & & 0,527 & 0,695 \\
\hline Smoking & $18(46,154)$ & $19(57,576)$ & & 0,751 & 0,814 \\
\hline ComQuol & & & & 0,153 & 0,163 \\
\hline
\end{tabular}

* Mean \pm SD- For non-categorical variables; † n (\%)- For categorical variables; ₹ The HDF study group has 39 patients, and the non-HDF study group has 33 patients.

studies that have reported reductions in mortality with the use of high-flux membrane dialysers.

A benefit of high-flux membranes for patients who are on dialysis treatment for more than 3.7 years was shown in a study that investigated the dialysis dose and membrane flux among haemodialysis patients. Regarding total mortality, no significant decrease was observed in the patients who were treated with high-flux membrane dialysers. (17)

This study showed no significant differences between patients who were treated with high-flux membrane dialysers and those who were treated with standard dialy- sers, though this does not mean that there were no true differences between them, considering the relatively small number of study subjects and the low power of the study. We should also not forget that specific conditions in the Serbian health system may have influenced the results; these include the limited number of dialysis centres, the fact that a high number of patients travel more than two hours for dialysis treatment, which affects their quality of life, the limited number of available high-flux dialysers and the high average age of haemodialysis patients in the examined sample of patients $(57,3056 \pm 12,64314)$. 


\section{REFERENCES}

1. Opatrny K Jr, Opatrny S.Haemodialysis in the treatment of chronic kidney failure.Present Status. Vnitr Lek 2003; 49: 424-9.

2. Locatelli F, Mastrangelo F, Redaelli B et al. Effects of different membranes and dialysis technologies on patient treatment tolerance and nutritional parameters. The Italian Cooperative Dialysis Study Group. J Am Soc Nephrol 1995; 5: 1703-8.

3. Locatelli F, Martin Malo A, Hannedouche T, Loureiro A. Effect of membrane Permeability on Survival of Hemodialysis Patients. J Am Soc Nephrol 2009; 20: 645-654.

4. Kreusser W, Reirmann S, Vogelbusch G, Bartual J, SchulzeLohoff E. Effect of different synthetic membranes on laboratory parameters and survival in chronic haemodialyses patients. NDT Plus 2010; 3 (suppl 1): i12-i 19.

5. Cheung AK, Sarnak MJ, Yan G, et al; HEMO Study Group. Cardiac diseases in maintenance hemodialysis patients: Results of the HEMO Study. Kidney Int 2004; 65: 2380-2389.

6. Krane V, Krieter DH, Olschewski M, März W, Mann JF, Ritz E, Wanner C. Dialyzer membrane characteristics and outcome of patients with type 2 diabetes on maintenance hemodialysis. Am J Kidney Dis 2007; 49: 267-75.

7. Weissinger EM, Kaiser T, Meert N et al.: Proteomics: A novel tool to unravel the patho-physiology of uraemia. Nephrol Dial Transplant 2004; 19: 3068-3077.

8. Unruh M, Benz R, Greene T, Yan G, Bedhu S.Effects of haemodialysis dose and membrane flux on health-related quality of life in the HEMO Study. Kidney Int 2004; 66: 355-66.

9. Costanza R, Fischer B, Ali S, Beer C. An integrative approach to quality of life measurement, research, and policy. Sapiens 2008; 1: 1.1 .
10. Landreneau K, Lee K, Landreneau MD. Nephrol Nurs J.Quality of life in patents undergoing haemodialysis and renal transplantation-a meta analytic review. 2010; 37: 37-44.

11. Schiffl H. Prospective randomized cross-over long term comparison of online haemodiafiltration and ultrapure high-flux haemodialysis . Eur J Med Res 2007; 12: 26-33.

12. Ward A. R, Schmidt A, Hullin J, Hillerbrand F and Samtleben W. Comparison of On-Line Hemodiafiltration and High-Flux Hemodialysis: A Prospective Clinical Study. J Am Soc Nephrol 2000; 11: 2344-2350.

13. Gabutti L, Salvade I, Lucchini B, Soldini D and Burnier M. Haemodynamic consequences of changing potassium concentrations in haemodialysis fluids. BMC Nephrology 2011, 12: 14.

14. Goldberg IJ, Kaufman AM, Lavarias VA, Vanni-Reyes T, Levin NW. High flux dialysis membranes improve plasma lipoprotein profiles in patients with end-stage renal disease. Nephrol Dial Transplant 1996; 11 Suppl 2: 104-7.

15. Vanholder RC, Glorieux GL, De Smet RV. Back to the future: middle molecules, high flux membranes, and optimal dialysis. Hemodial Int 2003; 7: 52-7.

16. House AA, Wells GA, Donnelly JG, Nadler SP, Hebert PC.Randomized trial of high-flux vs low-flux haemodialysis:effects on homocysteine and lipids. Nephrol Dial Transplant 2000; 15:1029-34.

17. Garabed Eknoyan, Gerald J. Beck, Alfred K. Cheung et al. Effect of Dialysis Dose and Membrane Flux in Maintenance Hemodialysis. N Engl J Med 2002; 347: 2010-2019.

18. Locatelli F, Hannedouche T, Jacobson $S$ et al. The effect of membrane permeability on ESRD: design of a prospective randomised multicentre trial. J Nephrol 1999; 12: 85. 